\title{
The Impacts of a CSR Cultural Event Measured Felt Far Beyond the Financial Results*
}

\author{
Colmenero Ferreira Fernando ${ }^{1}$
}

\begin{abstract}
:
With this work we aim to present a case of Corporate Social Responsibility (CSR) in the historic, disadvantaged part of the city of Funchal. The mission is based on the biennial organisation of a cultural event: "ON Fusion Art by Porto Bay". Over three days a group of people from the Porto Bay Group puts together a cultural event with the voluntary participation of a group of local, mainland and international artists from different artistic areas and the resident community in the historic and disadvantaged part of the city, achieving an increase in the population's self-esteem and raising a significant sum of money which is donated to charitable causes. The study explains the genesis of the idea and the motivation behind it followed by the stages of publicity management for the event and concludes with the results of the impact the CSR initiative beyond its financial objectives.
\end{abstract}

Key Words:

Event Marketing, Cultural Events, Fusion Art, Corporate Social Responsibility

JEL Classification:

* Acknowledgments: We profoundly acknowledge Fabíola Pereira, Rubina Santos, António Pais and Virgílio Silva from Porto Bay Group for the organization of the event and the accessibility of the data without which this work would not have been possible.

${ }^{1}$ Universidad de Madeira, e-mail:fcf@uma.pt 


\section{Introduction}

The aim of this study is to present the successful case of a Corporate Social Responsibility (CSR) initiative in the historic and disadvantaged part of the city of Funchal on the island of Madeira. The study explains the genesis of the idea and the motivation behind it followed by the stages of promotion management for the event and concludes with the results of the impact of the event. The impacts are felt far beyond the financial results that literature points to in the majority of studies.

The Old Town of the city of Funchal, its revitalisation and reanimation is a problem that has motivated the Porto Bay group, which owns a hotel in this area - Porto Santa Maria. The group is convinced that the characteristics of this part of town lend themselves to more clearly defined and frequent cultural initiatives. This was the context that gave rise to the idea of promoting a cultural and social initiative that would promote both expressions of Fusion Art and interactivity with the surroundings.

In 2006, faced with the problems inherent to this part of town, namely the need to revitalise and breathe new life into it, the general manager of the Porto Santa Maria hotel sowed the seed of the idea of organising a social and cultural intervention in the Old Town of Funchal amongst a small group of colleagues from Porto Bay Hotels \& Resorts. The project won the support of the Board of Directors of the Porto Bay Group. The exercise of social responsibility was a much greater motivation than financial success.

The challenge was immense: with few financial resources (little more than the budget for the creation of an advertisement) the aim was to create an event that would boost the social value of the area and would, in one way or another, stimulate public and private local entities to look at the Old Town in a different light. More than an isolated event, the objective was to imbue the revitalisation and reanimation of the Historic Centre of Town with a sense of continuity.

The initiative was to fit the criteria for philanthropic CSR (Carroll \& Buchholtz, 2003); the organisation's initiatives are in keeping with the expectations of a society in which the people of the organisation are committed to initiatives or programmes that promote the well-being of the rest of society. Examples of philanthropy include contributions made by the organisation either in monetary terms or by making available the time or work of its executives and other employees; these are materialised in contributions to the arts, education or the community.

The initiative came to fruition in a biennial event - ON Fusion Art by Porto Bay that provided the opportunity to involve the community in the organisation and voluntary work of a group of local, mainland and international artists from different 
artistic areas such as: painting, sculpture, photography, interactive performances, dance and music. Consequently the event embodied a social affirmation for all who participated, prompting them to increase their level of participation.

\section{Theoretical Elements}

The evolution of the concept and definition of Corporate Social Responsibility (CSR) has been an ongoing phenomenon since the 1950's which marked the modern era of CSR (Carroll, 1999; Schwartz \& Carroll, 2003; Thalassinos \& Zampeta, 2012). There are many examples in Southern European countries where organisations over five centuries old, independent of the state and connected above all to the Catholic Church, continue to pursue their path of social intervention. However, the concept and definitions of CSR expanded during the last decades of the 1900's and some of their components are now coming to maturity (Frederick, 1994). These include the business ethics theory, corporate social performance (CSP) and the theory of stakeholder.

Most research into CSR has focused on the efficacy of its implementation, on its antecedents and consequences and, above all, on financial performance (McWilliams \& Siegel, 2000; Marquez \& Fombrun, 2005; Barnett \& Salomon, 2006). However, in the meantime we know from existing research that individuals have different and relative expectations and attitudes in relation to CSR in industry (Bansal \& Roth, 2000; Havlíček, Břečková \& Zampeta 2013).

Carroll (1991) classifies CSR into four categories of social responsibilities: economic, legal, ethical and philanthropic. These four categories or components of CSR constitute CSR as a whole and, furthermore, are grouped in the form of a pyramid. Carroll \& Buchholtz (2003) clearly specify the different nature of social responsibility and state that these kinds of responsibilities have always existed to a certain extent, however, ethical and philanthropic functions have only assumed an important role in the last years.

Philanthropy covers the organisations' actions that are in keeping with the expectations of society that people belonging to the organisation are good citizens committed to initiatives or programmes that promote the well-being of the rest of society. Examples of philanthropy include contributions made by the organisation either in monetary terms or by making available the time or work of its executives and other employees; these are materialised in contributions to the arts, education or the community (Carroll \& Buchholtz, 2003).

The distinguishing feature of philanthropy in relation to ethical responsibilities is that the former is not imbued with a moral sense. The community expects the 
organisation to make financial contributions, make premises available and allow their staff to invest time in humanitarian programmes or objectives but it does not consider the organisation unethical if it does not contribute as expected. Therefore, on the part of the organisation philanthropy is more discretionary or voluntary.

Studies suggest that organisations that develop a reputation for being socially responsible and ethical benefit from higher levels of performance. However, the ultimate motivation for organisations to practice social responsibility should not be financial but rather moral and ethical (Marquez \& Fombrun, 2005).

Event marketing is a tool for experiential marketing that focuses on the consumer's experience and approaches the consumer process rationally and emotionally as a holistic experience. The experiences often involve sensory, emotional, cognitive, behavioural and relational values that substitute functional values (Schmitt, 1999). The events offer an opportunity to involve the consumer with the organisation, its products and brands, and with the community (Close, Finney, Lacey \& Sneath, 2006; Thalassinos, Havlíček \& Berezkinova, 2012). As such, these events invest the participants with a sense of social affirmation, prompting them to increase their level of participation. As a result, participants are more apt to being receptive to the marketing messages and images associated to the event above and beyond other means of publicity (Pope \& Voges, 1999).

The number of organisations that sponsor events has increased over the last ten years. However, it is still not very clear how the efficacy of marketing activities at events can be measured. Sneath, Finney \& Close (2005) discuss the role of event marketing as a means of communication and, supported by a study of the philanthropic sponsorship of a sporting event, provide empirical evidence for the inclusion of event marketing in the organisation's promotional mix, namely through the positive influence that the sponsorship of an event has on the individuals who go to the events and on the community. Wohlfeil \& Whelan (2005) present empirical evidence from a qualitative field experiment at the Guinness Storehouse in Dublin of how brands can be communicated as experiential, 3-dimensional, real-lived experiences, reinforcing emotional ties to the brand by developing and implementing creative event-marketing strategies.

\section{The Research Strategy}

Bearing in mind the subject of the research and the problems in pinning it down, a quantitative approach is difficult to implement, however, the qualitative data may permit us to understand and explain this phenomenon. We could therefore describe these little studied phenomena by means of the relationship between the various participants involved (Eisenhardt, 1989; Marshall \& Rossman, 2006). This is especially true since the qualitative methodologies permit us to study the processes 
within the scope of a context, to situated them (Yin, 2002) and understand the constraints imposed on them (Denzin \& Lincoln, 2000). According to Lee (1999) these methods are appropriate to establishing a context, a precise description, a dynamic (and as far as possible, causal) structuring of the members of the organisation and a vision of the world to which the people being studied belong.

The positioning of our research may be resumed as the application of the case study method involving a detailed examination of the event by means of longitudinal analysis that provides a systematic means of looking at the event, collecting data, analysing information and reporting results (Yin, 1993) specifically from a social and cultural point of view.

\subsection{Porto Bay Group}

The Porto Bay Group was born of the idea of designing hotels perfectly aligned to market requirements in terms of premises and service with a view to providing top quality products and services. Investment was made by a group of private investors from Madeira (Portugal) some of whom already had experience in this sector.

In 2000 the urban resort, Porto Santa Maria, welcomed its first guests. This project was rooted in the concept of fusing a city hotel - it is located right in the centre of Funchal in the old town - with a resort.

Currently Porto Bay Hotels \& Resorts has a total capacity of 2,600 beds in four and five star hotels on the island of Madeira; it is present in the Brazilian market, namely in Rio de Janeiro and Búzios, and in the Algarve in the south of Portugal. The hotels are diverse in terms of concept but retain a similar positioning based on the quality guarantee of the Porto Bay Hotels \& Resorts brand.

At present the group is controlled by two Madeira-based organisations: the Ocean Island and Blandy groups each of which own $45 \%$ of the capital. The remaining $10 \%$ is owned by local businessmen. The German tour operator, Thomas Cook AG, holds a $15 \%$ share in an associated management company.

\subsection{Project}

In 2006, faced with the problems inherent to this part of town, namely the need to revitalise and breathe new life into it, the general manager of the Porto Santa Maria hotel sowed the seed of the idea of organising a social and cultural intervention in the Old Town of Funchal amongst a small group of colleagues from Porto Bay Hotels \& Resorts. The project won the support of the Board of Directors of the Porto Bay Group. The exercise of social responsibility was a much greater motivation than financial success. 
The challenge was immense: with few financial resources (little more than the budget for the creation of an advertisement) the aim was to create an event that would boost the social value of the area and would, in one way or another, stimulate public and private local entities to look at the Old Town in a different light. More than an isolated event, the objective was to imbue the revitalisation and reanimation of the Historic Centre of Town with a sense of continuity.

This was the context which, in 2006, saw the materialisation of the idea as a social and cultural initiative that would promote both expressions of "fusion art" and interactivity with the surroundings. It was named ON by Porto Bay.

The name was the key to the brand image in terms of the target audience, in other words, the choice was based on the following criteria: an alphabetic name that was universal, easy to write, pronounce and remember and that could live and grow hand in hand with the mother brand, communicating the concept: ON as in Old \& New, put into action, activate, invest with energy and evoke positive feelings.

No less important than the name was the definition of the slogan, the expression that the target audience would associate to the event and its positioning. Firstly, as an integral part of the logo, a short slogan, Fusion Art, was attributed - again easy to remember, communicating and summarising the concept of the event as well as aligned to strategy established for the project. Secondly, in order to reinforce the context in which these works of art are created, "live and in full colour" and thirdly, "leave your mark" appealing to participation by visitors to the event.

In general the project involves initiatives that combine distinct cultural and artistic styles and take place in the streets of the Old Town of Funchal. Artistic interventions in two unoccupied houses generously ceded by the owners, the live creation of works of art donated by the artists to the closing auction, various exhibitions: painting, sculpture and photography, interactive performances/installations, dance workshops, Brazilian capoeira, painting workshops, street entertainment, musical performances and a fair.

\subsection{Shared values}

Providing a stage for the different artistic qualities existing within the Porto Bay Group was a wish expressed by the CEO from the outset,

António Trindade (CEO of the Porto Bay Group): "Because, apart from day to day professional performance, it is important to motivate the development of other talents that enrich the company and its human resources."

Painting, photography, design and handicrafts were just some of the areas in which Porto Bay employees expressed their "other" talents during the event. 
ON culminates with an auction of the works of art created and generated during the event donated by the artists to the project. The funds raised by the auction of works of art are boosted by donations and revenue generated by the sale of merchandising and other products sold by all those who participate in the fair. All these funds are donated to charities, in this case, the Associação de Paralisia Cerebral da Madeira (Cerebral Palsy Association of Madeira) and the Centro de Acolhimento de São Tiago (São Tiago Shelter).

\subsection{Ambient}

Investing in a strategy that strengthens partnerships is fundamental to the success of the event. This means a concerted effort by all who are involved in the organisation of the event from suppliers to production, advertising, media, distribution, services, security, hygiene and, most importantly, the population of the Old Town. The event is undertaken in a spirit aimed at transmitting and maintaining trust, working in synergy with all involved, establishing good communication, acting with empathy and meeting expectations.

\subsection{Promotion}

With the local population, tourists and visitors as its target audience the ON publicity plan was essentially based on public relations, press conferences (presentation of the project), press releases and invitations to the media (regional and national) to cover the whole event; everything was duly monitored by means of press clippings.

Advertising was targeted at the press (advertisements, supplements about the Old Town of Funchal, documentaries on the artists participating in the event), the Internet (brand site, event blog and partner sites), 6-sheets, posters and programmes, mail-drops and an advertising billboard and the distribution of programmes at Funchal International Airport.

\section{The Impact}

\subsection{Financial}

The two editions of $\mathrm{ON}$ by Porto Bay have managed to raise and donate 65,000 euros (32,000 in 2006 and 33,000 in 2008) to charitable institutions. Considering that this was a new initiative with a regional scope that took place over three consecutive days, this appears to be a significant financial result equal to $23 \%$ of the funds raised by AMI (Fundação de Assistência Médica Internacional - Foundation for International Medical Assistance) during their 4 day street collection programme in 14 cities all over Portugal. 
The sum handed over by ON by Porto Bay to the Associação de Paralisia Cerebral da Madeira represented $40 \%$ of all funds raised by this association during 2008 .

The auction of works of art donated by the artists who created them during the event represents a significant part of the funds raised, however, the reward lies beyond the scope of financial motivation as recorded in the words of the artist, Diana Freitas: Diana Freitas (Artist): "It was very productive because I was able to show my work and, in terms of promotion, it was excellent. I donated two paintings that I did during these days and I did so with pleasure because they are going to a worthy cause." (Saber Madeira magazine, October 2008)

\subsection{Cultural and social}

From thirty one partnerships that were established for the first edition of the event, the figure rose to fifty in the second edition and there is growing interest from other organisations to become involved in the next edition. In this regard we quote the artist Joana Rêgo:

Joana Rêgo (Artist): "I took part in ON Fusion Art by Porto Bay for the second time and once again I am delighted to have had the privilege of participating in such an interesting event. It was again a very stimulating mixture of fun, learning and very enjoyable moments as well as an opportunity to meet very interesting people and take part in a project that I believe to be one of the best organised I have ever participated in or known of. Just the feeling that it is never enough makes one want to stay a few more days and make the most of the party atmosphere and Madeira's fabulous climate. I hope that the initiative will carry on and become more and more successful; I will always be ready to take part in it" (Saber Madeira magazine, October 2008)

In social and cultural terms ON by Porto Bay did, to a certain extent, put the Old Town of Funchal back on the map for many of its citizens and aroused the interest of visitors. In this respect the Vice-President of the Câmara Municipal do Funchal (Funchal Town Hall) had the following to say:

Bruno Pereira (Vice-President of the Câmara Municipal do Funchal): "The private sector plays a key role in bringing the area alive, a good example of which is the biennial ON by Porto Bay which the hotel group has developed over the last four years and which has born fruit at various levels" (www.dnoticias.pt, $19^{\text {th }}$ October 2008)

The sculptor Daniel Henriques emphasises the social and cultural importance of the event as a justification for its realisation every year:

Daniel Henriques (Sculptor): "In my opinion this event should take place every year because it is worthwhile, necessary and important both from the cultural and social solidarity points of view”, (Saber Madeira magazine, October 2008) 
The choreographer and person responsible for the Dançando com a Diferença (Dancing with Diversity) group, the Madeira-based group which is breaking new ground both on a national and international level, presenting inclusive dance and musical performances performed by people with and without special needs, declares that the values behind the cause are the motivation for participation in the event: Henrique Amoedo (Responsible for the Dançando com a Diferença Group): "This is a very important and worthwhile event. This time we were invited to support the cause and that, in part, reflects an artistic recognition of our work", (Saber Madeira magazine, October 2008)

\subsection{News clipping report}

Considered to be an unprecedented initiative by the national and regional media, the event generated significant impact in terms of the number and quality of news articles and promotion.

Over 4 months (August to November 2008) the event generated 26 regional and 24 national news reports in the following media channels: Internet, daily and weekly newspapers, magazines, television and radio. The event was essentially covered in the tourism and leisure, culture, business and general columns. One particularly significant piece of coverage was the 7 page article featuring the event in the weekly magazine, Notícias Magazine, (the leading magazine in Portugal in terms of circulation) and the 4 pages in Tabu magazine distributed with the weekly newspaper Sol (ranked second in Portugal in terms of circulation).

Of all the approximately 50 articles, 22 mentioned the brand name in the title and 21 also featured a photograph totalling 138 photographs published.

\section{Conclusion}

The main objective of this study was to raise issues that seem to be ripe for further research: is there a correlation between CSR and citizenship? Can a CSR event be measured beyond its financial impact? In this respect we resorted to a case study methodology, contributing, in our opinion, to a new perspective in this area of study. However, our work has many failings and limitations specific to the exploratory nature of the Case Study method.

ON Fusion Art By Porto Bay is an event affiliated to a CSR initiative which has great potential and is clearly associated to a profound sentiment of citizenship. However, the aspired sense of continuity for revitalisation and reanimation has not been achieved and, today, the Old Town of Funchal is still awaiting other people, other interventions, other creative initiatives with a view to belonging to the circuit 
of European cities in which the main square reaches out to touch many senses: sight, smell and hearing.

It seems that, from our experience, there is a need to create a more human, better conserved, culturally active, historic centre cared for by the locals with a view to a positive impact on all the community, both resident and visiting. However, Porto Bay Hotels \& Resorts' core business is the hotel trade and the revitalisation and reanimation of the Old Town of Funchal requires many, more frequent and more varied initiatives throughout the year. We hope that this project has awoken the desire in other players to make a contribution with other initiatives.

\section{References}

Bansal, P. and Roth, K. (2000), "Why companies go green: A model of ecological responsiveness", Academy of Management Journal, 43 (4), pp. 717-736.

Barnett, M.L. and Salomon, R.M. (2006), "Beyond dichotomy: the curvilinear relationship between social responsibility and financial performance", Strategic Management Journal, 27 (11), pp. 1101-1122.

Carroll, A.B. (1991) "The Pyramid of Corporate Social Responsibility: Toward the Moral Management of Organizational Stakeholders”, Business Horizons, 34 (4), pp. 39-48.

Carroll, A.B. (1999), "Corporate social responsibility: evolution of a definitional construct", Business \& Society, 38 (3), pp. 268-295.

Carroll, A.B. and Buchholtz, A.K. (2003), Business and Society: Ethics and Stakeholder Management, (5th ed.), Thomson South-Western.

Close, A.G., Finney, R.Z., Lacey, R.Z. and Sneath, J.Z. (2006), "Engaging the consumer through event marketing: Linking attendees with the sponsor, community, and brand", Journal of Advertising Research, 46 (4), pp. 420-433.

Denzin, N.K and Lincoln, Y.S. (2000), "Introduction: The Discipline and Practice of Qualitative Research", N.K. Denzin \& Y.S. Lincoln (Eds.), Handbook of Qualitative Research, (2nd Ed.), Thousand Oaks, CA: Sage Publications.

Eisenhardt, K.M. (1989), "Building Theories from Case Study Research", The Academy of Management Review, 14 (4), pp. 532-550.

Frederick, W. (1994), "From CSR1 to CSR2 - The Maturing of Business-and-Society Thought", Business \& Society, 33(2), pp. 150-164.

Garriga, E. and Melé, D. (2004), "Corporate Social Responsibility Theories: Mapping the Territory", Journal of Business Ethics, 53(1-2), pp. 51-71.

Havlíček, K., Břečková, P. and Zampeta, V. (2013), "Quality Management as a Part of CRM", European Research Studies Journal, Vol. XVI (4), Special Issue in SME's, pp. 15-28.

Lee, T.W. (1999), Using Qualitative Methods in Organizational Research, Thousand Oaks, CA: Sage Publications.

Marshall, C. and Rossman, G.B. (2006), Designing Qualitative Research, (4th Ed.), Thousand Oaks, CA: Sage Publications. 
McWilliams, A. and Siegel, D. (2000), "Corporate social responsibility and Financial Performance: Correlation or Misspecification?”, Strategic Management Journal, 21, pp. 603-609.

Marquez, A. and Fombrun, C.J. (2005), "Measuring Corporate Social Responsibility", Corporate Reputation Review, 7 (4), pp. 304-308.

Pope, N.K. and Voges K.E. (1999), "Sponsorship and image: a replication and extension", Journal of Marketing Communications, 5 (1), pp. 17-28.

Schmitt, B.H. (1999), "Experiential Marketing: How to get customers to sense, feel, think, act, and relate to your company and brands", New York, NY: The Free Press.

Schwartz, M.S. and Carroll, A.B. (2003), "Corporate Social Responsibility: A Three-Domain Approach”, Business Ethics Quarterly, 13 (4), pp. 503-530.

Sneath, J.Z., Finney, R.Z. and Close A.G. (2005), “An IMC Approach to Event Marketing: The Effects of Sponsorship and Experience on Customer Attitudes", Journal of Advertising Research (2005), 45 (4), pp. 373-381.

Thalassinos, I.E. and Zampeta, V. (2012), "How Corporate Governance and Globalization Affect the Administrative Structure of the Shipping Industry", Journal of Global Business and Technology, Vol. 8(1), pp. 48-52.

Thalassinos, I.E., K. Havlíček and Berezkinova, L. (2012), "Innovation Management and Controlling in SMEs", European Research Studies Journal, Vol. XV(4), Special issue in SME's, pp. 110-123.

Wohlfeil, M. and Whelan, S. (2005), "Event-Marketing as Innovative Marketing Communications: Reviewing the German Experience", Journal of Customer Behaviour, 4 (2), 181-207.

Yin, R.K. (1993), Applications of Case Study Research, Beverly Hills, CA: Sage Publications

Yin, R.K. (2002), Case Study Research: Design and Methods, (3rd Ed.), Thousand Oaks, CA: Sage Publications. 